\title{
Spectrophotometric Determination of Selenium with 1-Naphthyloamine-7-sulfonic Acid
}

\author{
Krystyna Pyrzyńska \\ Department of Chemistry, University of Warsaw, Pasteura 1, 02-093 Warsaw, Poland
}

\begin{abstract}
The conditions for a spectrophotometric determination of selenium with 1-naphthyloamine-7-sulfonic acid (Cleve's acid) are presented. $\mathrm{Se}^{\mathrm{IV}}$ forms a yellow complex with this ligand in sulfuric acid media with maximum absorbance at $350 \mathrm{~nm}$. The molar absorptivity is $8.9 \times 10^{4} 1 \mathrm{~mol}^{-1} \mathrm{~cm}^{-1}$. The calibration curve is linear up to $3.0 \mu \mathrm{g}$ of selenium with Sandell's sensitivity being $0.0009 \mu \mathrm{g} \mathrm{cm}^{-2}$, i.e., the amount of Se in a column of unit cross-sectinal area which gives the absorbance of 0.001 . The interference of various ions was studied. The method was applied for the determination of selenium in a vitamin supplement.
\end{abstract}

Keywords Selenium, 1-naphthyloamine-7-sulfonic acid, spectrophotometry

In recent years, there has been growing interest in understanding the physiological role of selenium. This element is an essential nutrient for humans and animals, although excesses have been known to cause toxicity. ${ }^{1-3}$ On the other hand, selenium-deficiency syndromes have also been reported. Particularly its compounds protect the cell membranes from oxidative damage, catalyze reactions of the intermediate metabolism and inhibite the toxicity of some heavy metals. ${ }^{4,5}$ Apart from natural sources (mainly metal-sulfur minerals) selenium compounds can be widely spread throughout the environment as a result of the combusion of coal, as well as throughout industrial and agricultural processes.

On the basis of this background, the determination of selenium in different kinds of samples is becoming increasingly important. Reviews of the analytical methods for selenium determination are available in the literature. ${ }^{6-8}$ Each of the proposed methods has both advantages and disadvantages from the point of view of practicality for routine analysis. Most of them require specialized apparatus. Very popular and widely used are methods based on the spectrophotometric or fluorometric measurement of piazselenol, which is formed when $\mathrm{Se}^{\mathrm{IV}}$ reacts with aromatic $o$-amines. ${ }^{9-15}$ However, most of these methods require long reaction times and precise control of the $\mathrm{pH}$; also, the reagents are unstable to light and oxidants. ${ }^{16}$ A time-consuming extraction process of the Se-diaminonaphtalene complex was omitted and sodium dodecylsulfate (as surfactant) was proposed for enhancing the sensitivity of measurements. ${ }^{17}$ Although catalytic spectrophotometric methods are more simple and selective, they must be done during the first $0.5-3 \mathrm{~min}$ after mixing the reagents. ${ }^{18-22}$ Only a few automatic flow-injection systems have been used for selenium determination. ${ }^{18,19}$
In this paper, 1-naphtyloamino-7-sulfonic acid (Cleve's acid) is proposed as a new reagent for the spectrophotometric determination of selenium. The presented method is very simple, rapid and offers advantages of stability of a colored solution without heating.

\section{Experimental}

\section{Reagents}

Analytical-reagent grade chemicals were used for the preparation of all solutions with deionized water obtained from Milli-Q system (Millipore).

Selenium stock standard solutions were prepared from selenous acid (Riedel-de Haen) and ammonium selenate (Merck). Working standard solutions of lower concentrations were prepared daily by appropriate dilution.

Solutions of potentially interfering metal ions were prepared by dilution of $1000 \mathrm{mg} \mathrm{l}^{-1}$ stock standard solutions by Merck. They were used in the form of chlorides or sulfates.

A reagent solution was prepared by dissolving $25 \mathrm{mg}$ of 1-naphthyloamine-7-sulfonic acid (Cleve's acid) from $\mathrm{BDH}$ in $100 \mathrm{ml}$ of concentrated sulfuric acid, and store in an amber-colored bottle.

\section{Apparatus}

A Hewlett-Packard Model 8452A photodiode-array spectrophotometer furnished with an HP Vectra 286/12 personal computer was used for recording of the absorption spectra.

The absorbance of solutions was measured at $350 \mathrm{~nm}$ with a Spectronic (Model D20) spectrophotometer (Milton Roy) equipped with a $1-\mathrm{cm}$ cell. 
Procedure for the study of the color reaction

Into a $10 \mathrm{ml}$ volumetric flask an appropriate amount of sample containing not more than $3.0 \mu \mathrm{g}$ of $\mathrm{Se}^{\mathrm{IV}}, 0.8 \mathrm{ml}$ of Cleve's acid solution and $0.3 \mathrm{ml}$ of concentrated sulfuric acid were added, mixed well and diluted to the mark with water. The absorbance was measured at $350 \mathrm{~nm}$ against a reagent blank.

\section{Determination of Se in a vitamin supplement}

The sample was treated with $10 \mathrm{ml}$ of concentrated $\mathrm{HCl}$ and heated under a reflux condenser. Then, concentrated $\mathrm{HNO}_{3}(5 \mathrm{ml})$ was added and the mixture was heated on a water bath nearly to dryness. After cooling, the mineralized solution was transferred into a $50 \mathrm{ml}$ calibration flask and diluted to volume with water. Then, $5 \mathrm{ml}$ of the sample solution was taken for the determination of $\mathrm{Se}$ according to the recommended procedure.

\section{Results and Discussion}

\section{Conditions for complex formation}

The absorption spectra of selenium-Cleve's acid complex against a reagent blank are shown in Fig. 1 . $\mathrm{Se}^{\mathrm{IV}}$ reacts with 1-naphtyloamino-7-sulfonic acid to form yellow complex with maximum absorbance at $350 \mathrm{~nm}$. The reagent shows negligible absorption at this region. The composition of the complex was determined by the mole-ratio method and the ratio of Se-ligand was found to be $1: 2$.

The absorbance of the complex depends on the sulfuric acid concentration in the solution. The maximum absorbance was observed in the $\mathrm{H}_{2} \mathrm{SO}_{4}$ concentration range from 0.2 to $0.8 \mathrm{M}$ (Fig. 2). It is especially useful for the analysis of materials which require an acid treatment.

The optimum concentration of the reagent required to obtain constant absorbance for a $0.5 \mu \mathrm{g} / \mathrm{ml}$ Se solution was $0.9 \mathrm{mM}$. Therefore, $0.8 \mu \mathrm{l}$ of a $0.25 \%$ Cleve's acid solution was introduced into a 10 -ml volumetric flask for selenium determination. The color reaction requires no heating. After mixing the solutions, the absorbance reached its maximum immediately and remained stable for at least $4 \mathrm{~h}$.

Under the above conditions, the absorbance value was a linear function of selenium content over the range of $0.2-3.0 \mu \mathrm{g}$ of Se per $10 \mathrm{ml}$ final solution. The calibration graph can be represented by a regression equation, $y=1.150 x-1.705,(R=0.9978)$, where $y$ is the absorbance and $x$ is the concentration of selenium in $\mu \mathrm{g} / \mathrm{ml}$. The relative standard deviation for a concentration of $0.2 \mu \mathrm{g} /$ $\mathrm{ml}$ was $4.5 \%(n=6)$. The apparent molar absorptivity of the colored complex, calculated from the absorbance value, was found to be $8.9 \times 10^{4} 1 \mathrm{~mol}^{-1} \mathrm{~cm}^{-1}$. The Sandell's sensitivity [the amount of $\mathrm{Se}$ in a column of unit cross sectional area $\left(\mathrm{cm}^{2}\right)$, which gives the absorbance of 0.001$]$ was $0.0009 \mu \mathrm{g} \mathrm{cm}^{-2}$.

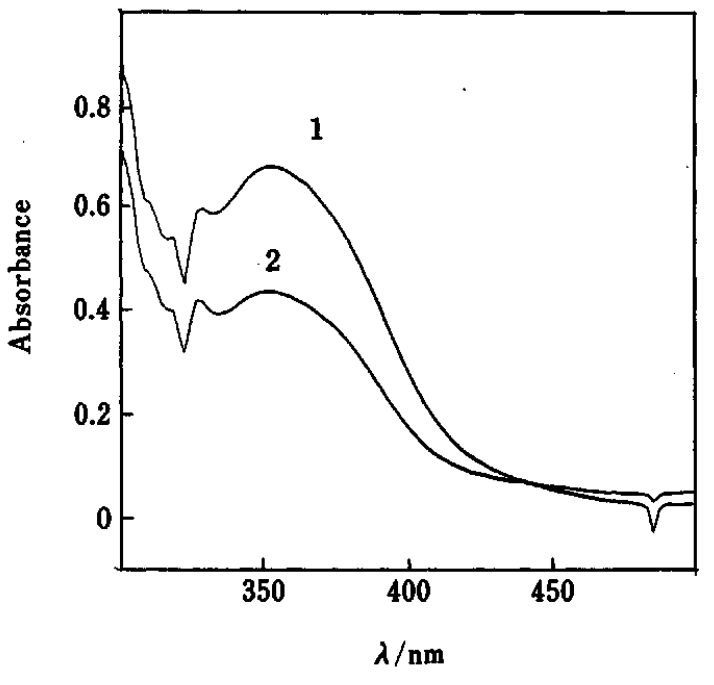

Fig. 1 Absorption spectra of selenium-Cleve's acid complex. Concentration of Se: (1) $0.7 \mu \mathrm{g} / \mathrm{ml}$ and (2) $0.5 \mu \mathrm{g} / \mathrm{ml}$.

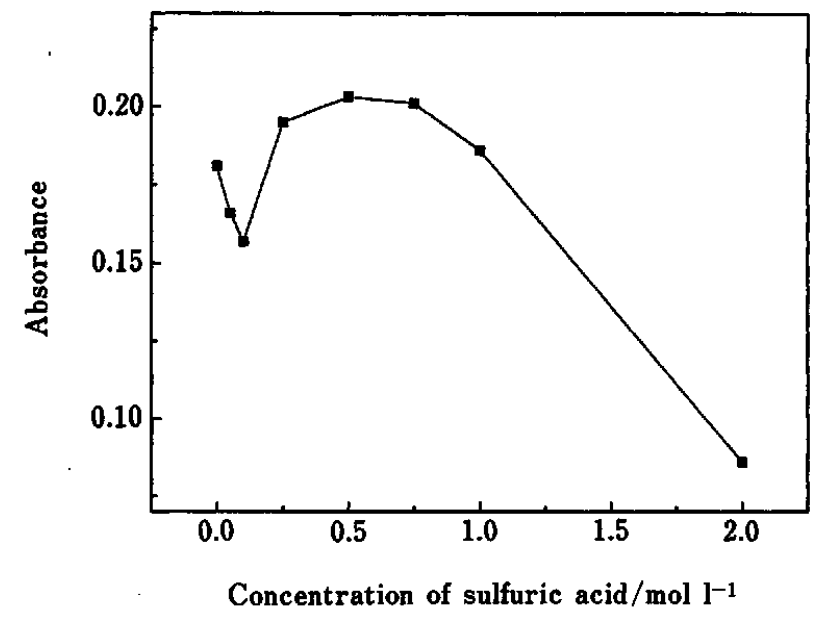

Fig. 2 Effect of the $\mathrm{H}_{2} \mathrm{SO}_{4}$ concentration on the absorbance: $[\mathrm{Se}]=0.2 \mu \mathrm{g} / \mathrm{ml}$.

\section{Effect of diverse ions}

After different concentrations of individual interferent ions were added to a selenium standard solution $(0.2 \mu \mathrm{g} /$ $\mathrm{ml}$ ), followed by other reagents, the earlier described procedure was applied. The tolerance ratios, which were defined as the concentration of added ion causing less than a $5 \%$ relative error in the determination of selenium are given in Table 1 . Of the studied ions, $\mathbf{F e}^{\mathrm{III}}$ has the lowest tolerance ratio, followed by $\mathrm{Co}^{\mathrm{II}}$ and $\mathrm{Cr}^{\mathrm{II}}$. It was previously found that $\mathrm{Fe}^{\mathrm{III}}$ seriously interferes in the spectrophotometric determination of selenium. $9,14,23$ According to Tanaka $e t$ al. ${ }^{23}$ the tolerated amount of iron for the reaction of selenium $(25 \mu \mathrm{g})$ with 1,2 -diphenylenediamine is $1 \mathrm{mg}$. To the contrary, Ramachdran et al. ${ }^{13}$ reported the color reaction of $\mathrm{Se}^{\mathrm{IV}}$ with 6-amino-1naphthol-3-sulfonic acid ( $\mathrm{J}$-acid) was free from any intrerference of $\mathrm{Fe}^{\mathrm{III}}$ and $\mathrm{Fe}^{\mathrm{II}}$, even at 2500 -fold excess. 
Table 1 Tolerance ratios for interfering metal ions on the determination of $0.2 \mu \mathrm{g} / \mathrm{ml} \mathrm{Se}^{\mathrm{IV}}$

\begin{tabular}{lc}
\hline \multicolumn{1}{c}{ Metal ion } & Tolerance ratio $^{\mathrm{a}}$ \\
\hline $\mathrm{Na}, \mathrm{K}$ & 2500 \\
$\mathrm{Mg}$ & 2000 \\
$\mathrm{Ca}$ & 500 \\
$\mathrm{Cu}^{\mathrm{II}}, \mathrm{Ni}^{\mathrm{II}}$ & 200 \\
$\mathrm{Cd}^{\mathrm{II}}, \mathrm{Sb}^{\mathrm{III}}, \mathrm{Al}^{\mathrm{III}}$ & 80 \\
$\mathrm{Co}^{\mathrm{II}}, \mathrm{Cr}^{\mathrm{III}}$ & 60 \\
$\mathrm{Fe}^{\mathrm{III}}$ & 50 \\
\hline
\end{tabular}

a. Tolerance ratio is defined as the ratio of the concentration of the interfering ion to the concentration of Se when the interferent causes a $\pm 5 \%$ change in absorbance compared to a solution containing $0.2 \mu \mathrm{g} / \mathrm{ml} \mathrm{Se}$.

Table 2 Interference of $\mathrm{Fe}^{\mathrm{III}}$ on the determination of $0.2 \mu \mathrm{g} / \mathrm{ml} \mathrm{Se} \mathrm{IV}^{\mathrm{IV}}$ in the presence of masking agents

\begin{tabular}{ccccc}
\hline \multirow{2}{*}{$\begin{array}{c}\text { Concentration } \\
\text { of } \mathrm{Fe}^{\mathrm{III}} / \mathrm{mg} \mathrm{l}^{-1}\end{array}$} & \multicolumn{4}{c}{ Recovery of selenium, \% } \\
\cline { 2 - 5 } & $\begin{array}{c}\text { Without } \\
\text { agent }\end{array}$ & $\begin{array}{c}0.4 \mathrm{mM} \\
\mathrm{KF}\end{array}$ & $\begin{array}{c}1 \mathrm{mM} \\
\mathrm{H}_{2} \mathrm{C}_{2} \mathrm{O}_{4}\end{array}$ & $\begin{array}{c}6.4 \mathrm{mM} \\
\text { EDTA }\end{array}$ \\
\hline 10 & 95 & 99 & 97 & 96 \\
20 & 70 & 99 & 96 & 81 \\
50 & 44 & 97 & 103 & 70 \\
\hline
\end{tabular}

To decrease the interference from iron, ethylenediaminetetraacetic acid (EDTA), oxalate and fluoride were examined as masking agents (Table 2). The experiments with EDTA were unsuccessful, because this agent (even in the absence of metal ions) caused negative interferences in the selenium determination. Similar observations were described earlier. ${ }^{19}$ Although Huang et al. ${ }^{17}$ reported that the presence of fluoride ions caused an error of about $-60 \%$ in the determination of Se with diaminonaphthalene, they tested their higher concentration $(2 \mathrm{mM})$. In our procedure, the interfering effect of $\mathrm{Fe}^{\mathrm{III}}$ in concentrations higher than $10 \mathrm{mg} / \mathrm{l}$ could be eliminated by the addition of $1 \mathrm{ml}$ of $4 \mathrm{mM}$ potassium fluoride to the sample solution.

To further improve the selectivity of the proposed method for the spectrophotometric determination of selenium with 1-naphtholamine-7-sulfonic acid, a separation step should be helpful. Such a sample pretreatment also allows an improvement in the sensitivity of the determination. In our earlier work ${ }^{24}$ the functionalized cellulose sorbent Cellex $\mathrm{T}$ (from Bio Rad) with quaternary amine exchange groups was successfully applied for the preconcentration of inorganic selenium species in the presence of excess metal ions. This sorbent was tested for the separation of selenium to preclude any interference. A $50 \mathrm{ml}$ sample solution containing $0.05 \mu \mathrm{g} / \mathrm{ml}$ $\mathrm{Se}$ in the presence of $\mathrm{Fe}^{\mathrm{III}}, \mathrm{Cr}^{\mathrm{III}}, \mathrm{Cu}^{\mathrm{II}}, \mathrm{Co}^{\mathrm{II}}, \mathrm{Ni}^{\mathrm{iI}}, \mathrm{Cd}^{\mathrm{II}}$ and $\mathrm{Zn}^{\mathrm{II}}$ (each at $50 \mathrm{mg} / \mathrm{l}$ concentration) was pumped through the column with $0.6 \mathrm{~g}$ of Cellex $\mathrm{T}$. The retained $\mathrm{Se}^{\mathrm{IV}}$ was eluted with $5 \mathrm{ml}$ of $0.05 \mathrm{M} \mathrm{HCl}$, and after the

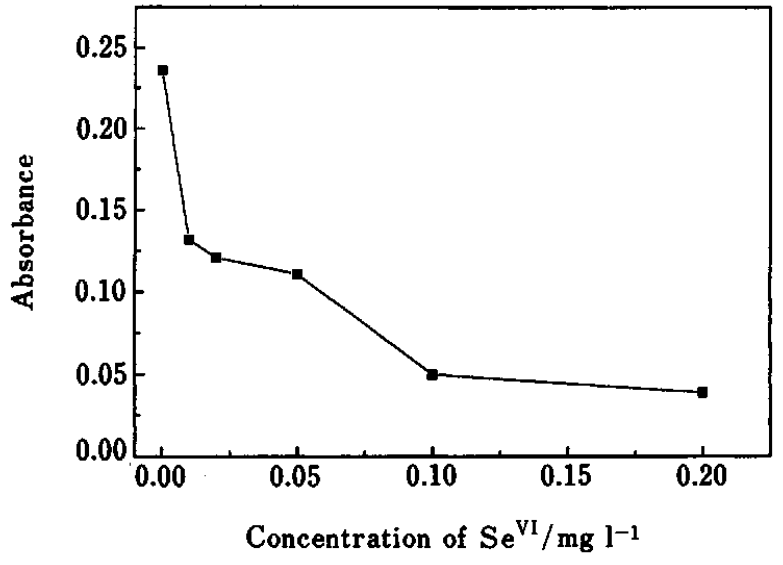

Fig. 3 Influence of $\mathrm{Se}^{\mathrm{VI}}$ on the spectrophotometric determination of $\mathrm{Se}^{\mathrm{IV}}$ with Cleve's acid reagent: $\left[\mathrm{Se}^{\mathrm{IV}}\right]=0.2 \mu \mathrm{g} / \mathrm{ml}$.

addition of the reagent was determined by the proposed spectrophotometric method. The recovery of selenium was $97 \pm 2 \%$. The optimized general preconcentration procedure for trace selenium should consist of passing the solution at $\mathrm{pH}$ 6-8 with volumes not greater than $200 \mathrm{ml}$ at a flow rate up to $5 \mathrm{ml} / \mathrm{min}$.

Recovery experiments were carried out with seleniumspiked $\left(40 \mu \mathrm{g} / \mathrm{ml}\right.$ and $80 \mu \mathrm{g} / \mathrm{ml}$ of $\left.\mathrm{Se}^{\mathrm{IV}}\right)$ ground-water samples. Selenium was preconcentrated on a microcolumn filled with Cellex $T$, and after the addition of reagents determined with Cleve's acid. The recovery was $93 \%$ and $95 \%$ with relative standard deviations (RSD) of $8.3 \%$ and $4.7 \%$, respectively $(n=5)$.

The biological effect of selenium is dependent on its chemical form, with a different toxicity being exhibited for inorganic and organic compounds. Selenite and selenate are the major inorganic compounds which affect the behavior of this element in an aquatic system. The reported spectrophotometric methods respond only to $\mathrm{Se}^{\mathrm{IV}}$. The selenate content is usually obtained by the difference after reduction to selenite. To check the possibility of a selenium speciation analysis the effect of the presence of $\mathrm{Se}^{\mathrm{VI}}$ was examined (Fig. 3). Unfortunalety, selenate strongly interferes by changing the color of the solution, probably by the oxidization of the reagent. For this reason the proposed spectrophotometric method can be applied only to the determination of the total selenium, after reduction to Serv ${ }^{\mathrm{Iv}}$ Critital examination of some common reagents for reducing selenium species in a chemical analysis was made by Bye. ${ }^{25}$ From these experiments it seems that chloride is the most reliable reductant for $\mathrm{Se}^{\mathrm{vI}}$ to $\mathrm{Se}^{\mathrm{iv}}$. Moreover, reduction by chloride can be done in both sulfuric and perchloric acid media. To convert selenium to $\mathrm{Se}^{\mathrm{IV}}$ prior to the determination, $\mathrm{MgCl}_{2}$ was added to sample solutions in amounts that allowed us to maintain the concentration of $\mathrm{Cl}^{-}$in the range of $0.5-2 \mathrm{~mol} \mathrm{l}^{-1} .25$ Under such conditions the reduction of selenate is quantitative, and chloride ions do not influence the spectrophotometric determination of $\mathrm{Se}^{\mathrm{IV}}$ with Cleve's 
acid. It is noteworthy to add that, to our best knowlegde, no influence of $\mathrm{Se}^{\mathrm{VI}}$ on the spectrophotometric determination of $\mathrm{Se}^{\mathrm{IV}}$ with different reagents was examined.

\section{Determination of selenium in a vitamin supplement}

In order to test the proposed method, selenium was determined in such pharmaceutical samples as Eko-vit tablets (from Curtis Healthcare). Acid digestion converts selenium into selenite. ${ }^{18} \mathrm{KF}$ was added to the samples to eliminate any iron interference. The results shown the mean selenium content of $0.020 \pm 0.007 \mathrm{mg} / \mathrm{g}$ $(n=6)$; a comparison with the average value of $0.021 \mathrm{mg} /$ g obtained by us using the 2,3-diaminonaphthalene method ${ }^{17}$ is quite satisfactory.

In conclusion, Cleve's acid is proposed as the sensitive reagent for the spectrophotometric determination of selenium. The proposed method requires only simple and cheap equipment. It should be quite easy to automate by applying a flow-injection technique. Moreover, the preconcentration step utilizing a solid sorbent (Cellex T) improves the detection limit and can be used for removing any matrix interference.

This study was supported by grant from the Nation Committee for Scientific Research, GR-684/96 project.

\section{References}

1. .K. Forchhammer and A. Bock, Naturwissechaften, 28, 497 (1991).

2. R. A. Zingaro and W. C. Cooper, "Selenium", Chap. 11, Van Nostrand Reinhold, New York, 1974.

3. E. J. Underwood and W. Mertz, in "Trace Elements in Human and Animal Nutriton", ed. W. Mertz, pp. 1-19, Academic Press, San Diego, 1975.
4. L. Magos and M. Webb, Crit. Rev. Toxicol., 8, 1 (1990).

5. R. J. Shamberger, Sci. Total Environ., 17, 59 (1991).

6. R. M. Olivas, O. F. X. Donard, C. Camara and P. Quevaviller, Anal. Chim. Acta, 286, 357 (1994).

7. X. Dauchy, M. Potin-Gautier, A. Astruc and M. Astruc, Fresenius'J. Anal. Chem., 348, 792 (1994).

8. K. Pyrzyńska, Chem. Anal. [Warsaw], 40, 677 (1995).

9. B. G. Russel, Talanta, 14, 957 (1967).

10. Y. Shimoishi and K. Toei, Anal. Chim. Acta, 100, 65 (1978).

11. M. E. Bodini, J. Pardo and V. Arancibia, Talanta, 37, 429 (1990).

12. V. Stibij, M. Dermejl, M. Franko and A. R. Byrne, Anal. Sci., 10, 789 (1994).

13. K. N. Ramachdran, R. Kaveeshwar and V. K. Gupta, Talanta, 40, 781 (1994).

14. R. Manish, K. N. Ramachandran and V. K. Gupta, Talanta, 41, 1623 (1994).

15. B. Kasterka, Mikrochim. Acta [Wien], 106, 303 (1992).

16. R. F. Bayfield and L. F. Romalis, Anal. Biochem., 144, 569 (1985).

17. X. Huang, N. Jie, W. Zhang, Y. Yin and H. Shao, Fresenius' J. Anal. Chem., 354, 195 (1996).

18. C. Martinez-Lozano, T. Perez-Ruiz, V. Tomas and C. Abellan, Analyst [London], 114, 715 (1989).

19. P. M. Shindu and A. P. Wade, Anal. Chem., 63, 692 (1991).

20. A. Afkhani, A. Safavi and A. Massoumi, Talanta, 39, 993 (1992).

21. I. G. Gokmen and E. Abdelgader, Analyst [London], 119, 703 (1994).

22. A. A. Ensafi and G. B. Dehaghi, Anal. Lett., 28, 335(1995).

23. M. Tanaka and T. Kawashima, Talanta, 12, 211 (1965).

24. K. Pyrzyńska, Analyst [London], 120, 1933 (1995).

25. R. Bye, Talanta, 30, 993 (1983).

(Received February 12, 1997) (Accepted April 22, 1997) 